\title{
ARTIST'S CREATIVE CONTRIBUTIONS IN THE CONTEXT OF INTERDISCIPLINARY RESEARCH
}

\author{
Kyong-Mi PAEK \\ Ulsan National Institute of Science and Technology, Division of General Studies, \\ 50 UNIST-gil, Ulsan 44919, South Korea
}

Received 26 February 2019; accepted 11 April 2019

\begin{abstract}
While expectations regarding art's potential contributions to the interdisciplinary research context continue to grow, the creative endeavors of individual artists remain under-examined, perhaps because of the inter-relational nature of joint research settings. To explore, how artists navigate their contribution to a given research community, this study reviews the art practice of Seung-Hyun Ko, who participated in Science Walden, a Convergent Research Center carrying out an interdisciplinary research project that aimed to build an ecologically sustainable community. Drawing on comprehensive views of creativity that emphasize the importance of the social context in which the efforts of individuals emerge and are assessed, the study examines Ko's recent collaborative practice in Science Walden within the larger context of his long-term practice as a leading artist of Yatoo, a bioregionally conscious artist community. Ko's responses to the opportunities and challenges of his involvement in these two interrelated contexts disclose the value of the creative dynamics of interdisciplinary research, with implications for the increasingly diverse interdisciplinary research practices emerging within science and technology.
\end{abstract}

Keywords: collaboration, comprehensive views, creative practice, interdisciplinary research, Science Walden, Yatoo.

\section{Introduction}

The increasing complexity of contemporary environmental issues and the destruction of the ecosystem require researchers to look beyond the traditional technocentric approach to more holistic and interdisciplinary efforts (Curtis, Reid, \& Ballard, 2012; Gurevitz, 2000; Hadzigeorgiou \& Skoumios, 2013; Jacobson, Seavey, \& Mueller, 2016). Susan K. Jacobson, Jennifer R. Seavey and Robert C. Mueller (2016) stressed the growing need to promote interdisciplinary understanding of the natural and built environment through science and the arts and humanities, as the integration of different perspectives allows problems to be solved more holistically and creatively. Additionally, given the inherent inability of conventional scientific and technocentric approaches to engage people (Curtis et al., 2012; Gurevitz, 2000;

\footnotetext{
*Corresponding author. E-mail: kpaek@unist.ac.kr
} 
Kollmuss \& Agyeman, 2002), there is increasing interest in creating opportunities to support for effective communication, public outreach, collective action and behavior change (Curtis et al., 2012).

This is the case for the a seven-year project (Fall 2015-Winter 2022) carried out by Science Walden $(S W)$, a Convergence Research Centre (CRC) based in the School of Environmental Engineering in a university in South Korea that conducts challenging science-art collaborations. Inspired by the humanistic values and integrated ways of living in Henry David Thoreau's Walden, Or Life in the Woods (1854) and B. F. Skinner's Walden Two (1948), the project explores ways of using advanced technologies to build the infrastructure for a more ecologically sustainable community. The project addresses the current planetary ecocrisis, driven by the rapid expansion of unsustainable socioeconomic practices informed by the dominant individualistic and anthropocentric worldview. Instead, SW adopts a holistic worldview to investigate ways of building an ecologically sustainable urban community operated by a "feces standard money" ("FSM") based economic system (Cho, 2017). In the community envisioned here, all inhabitants earn a basic income by having their excretions processed into an odorless powder by means of a non-flushing toilet system (Cho, 2019). The aim is to re-establish the urban community's ecological linkages by promoting recycling of feces that is generally flushed away through a waste disposal system. This ecotopian vision of the environment offers an alternative to the utopianism of modern industrialized culture, instead emphasizing the interconnectedness and interdependence of all living and non-living things (Garoian, 1998). What challenges us as the researchers is the fact that the idea of building communities based on this new resource recycling system requires a more comprehensive and collaborative approach that goes beyond the purely technological.

Collaboration with artists is a crucial part of this project because reconstructing communities on the basis of an FSM based local economy involves changes in long-established perceptions and attitudes rooted in the anthropocentric, efficiency-oriented culture of flushing toilets (Cho, 2017). Here, the expected role of art includes the propagation and accentuation of the project's vision as a catalyst for raising social awareness, changing perceptions, and constructing communities based on this new socioeconomic system, promoting the value created by the ecological circulation of natural resources. SW opted for this ecological art practice because of its capacity to promote critical inquiry regarding environmental awareness and sustainability, communicating issues and challenging dominant paradigms (Aguilar, Waliczek, \& Zajicek, 2008; Blandy, Congdon, \& Krug, 1998; Hollis, 1997; Jacobson et al., 2016; Kollmuss \& Agyeman, 2002; Neperud, 1997). To that end, two artists affiliated with Yatoo - an artist community known for its unique vision, based on a long-term commitment to working with nature (Paek, 2019) - were invited to work with other researchers from diverse disciplines that include urban and environmental engineering, economics, and arts and humanities.

\section{The need to define the creative contributions of artists}

Toward the end of the second year of collaboration, a qualitative review of the art practice was required both internally and externally, as the research team faced an interim evalua- 
tion of the project's first stage of development. In interdisciplinary research (IR) contexts, especially those involving complex sociocultural issues, artists are often invited to contribute innovative ideas and creative solutions (Inwood, 2008; Spaid, 2002; Walker, 2001). However, despite growing expectations in this regard, the inter-relational nature of joint research settings often obscures the creative endeavors of individual artists. As an insider who was in a better position to define the creative contributions of individual artists in the given context, I undertook a contextual review of the practice of Ko, one of the artists participating in SW.

\section{Method}

To explore how artists navigate their contributions to a research community's vision, this study adopted a comprehensive view (CV) that highlights the social dimension of the creative process (CP) (Csikszentmihalyi, 2014). Researchers who argue for a CV of creativity have suggested that creative ideas and actions arise during the interaction between person and context (Sternberg, 2006), implying that the CP can be observed only at the intersection where individuals, domains, and fields interact (Csikszentmihalyi, 2014). Paying attention to the contexts that influence the way creativity occurs and is encountered and mediated by socio-cultural forces is a relatively recent phenomenon in the tradition of creativity research. It only emerged in the latter decades of the 20th century through researchers who changed their questions from "what" creativity is to "when" creativity becomes manifest (Sullivan, 2007). Due to its emphasis on the importance of social context in the emergence and assessment of individual efforts, the $\mathrm{CV}$ of creativity provides a useful lens that explores creative art practice in relation to a convergence of social and contextual factors within a particular context of IR. In particular, this study examines Ko's recent collaborative practice in SW within the larger context of his long-term practice as a leading artist within the Yatoo community. The guiding questions for the contextual analysis are: "How does Ko respond to the challenges and opportunities in these two communities?" and "what do such responses imply for the potential role of art in the growing interdisciplinary research practice?".

The data referred to here were collected during the first stage of the project's development (Fall 2015-Winter 2016) in multiple formats that included observations, documents, and video and audio recordings of internal activities such as group meetings, seminars, and workshops. The primary data are accounts collected from 1) a 20-minute talk by Ko about his art practice (in January 2016) for an on-campus collaborative art project; 2) a 45-minute talk by Ko (in October 2016) about his experience of the SW project, as part of a departmental lecture series at my university; and 3) a further 60-minute unstructured telephone interview with Ko in December 2017 for clarification purposes following the initial data review.

To draw out the interplay of collaboration, four decades of Ko's practice were reviewed in relation to the distinct but interrelated communal contexts of Yatoo and SW. The contextual review of his practice is presented here as three sequential phases: working with nature in the 1980s and 1990s, sound creation practice in the 2000s, and extended practice since 2010. The discussion centers on the social dimensions of Ko's CP to clarify art's potential roles in IR practice. 


\section{The bioregional art practice of Seung-Hyun Ko}

Ko's identity has largely been shaped by his longstanding involvement in Yatoo, a bioregionally conscious artist community built on knowledge and profound love of the place where it is based (Thayer, 2003).

\section{1. Seyng-Hyun Ko's practice in the context of Yatoo}

Ko was born in 1956 and grew up in Gongju, a verdant city in the southwest of South Korea. Here, surrounded by mountains and a large river (the Geum River), Ko spent his boyhood playing in nature. From his early years, he liked to draw and make things, and he decided to apply to an art college. In our recent telephone interview, he noted that his art education both prior to college and in college encouraged him to focus mostly on skill development and media exploration. However, once he began his career as an artist, he began to consider ways of incorporating his early relationship with nature into his art practice.

In 1981, along with a few local artists in Gongju, he founded Yatoo. From its inception, Yatoo has defined itself as an outdoor art research group grounded in Southwest regionality. Seeking direct inspiration from nature, Yatoo artists pursue onsite experiences through direct encounters with nature. Their artwork is usually a spontaneous response to their feelings at a certain place, and they create works with a minimum of action or manipulation, using their bodies or locally found objects. Concentrating on the particularity of their local environment, Yatoo artists develop an affective sense of belonging to that region (Paek, 2019). Yatoo's bioregional orientation is clear from its inaugural statement: "Yatoo is a group studying outdoor art through fresh contact with nature and, based on a deep love for nature, appreciating its seasons $\langle\ldots\rangle$ its infinite breadth and depth and all life forces therein $\langle\ldots\rangle$ " (cited in Lee, 2000, p. 25).

The bioregional practice of Yatoo artists is among the alternative movements that arose in South Korean art in the late 1970s, led by young artists who sought to work beyond studio or gallery spaces, which were dominated by mainstream art practitioners (Jin, 2016). While most contemporary artists regard nature as a source of materials or as a place to display their artwork, Yatoo artists value nature as a source of inspiration and view their practice as a search for harmonious coexistence with nature rather than dominance over it (Jeon, 2016). This ecotopian vision, which rejects human-centric views of nature and stresses the interconnectedness of all things (Garoian, 1998), has shaped the identity of Yatoo artists over the past four decades.

\subsubsection{Working with nature in the 1980 s and 1990s}

As a major figure leading the Yatoo artists' collective journey, Ko stresses the importance of communing with nature through direct contact. As he explains, "[B]eing in nature allows me to breathe in nature and, through my five senses, feel its life force that brings seasonal changes". This idea has informed Ko's early practice from the 1980s onward (see Table 1). 
Table 1. Seung-Hyun Ko's 1980s works (source: Courtesy of Yatoo)

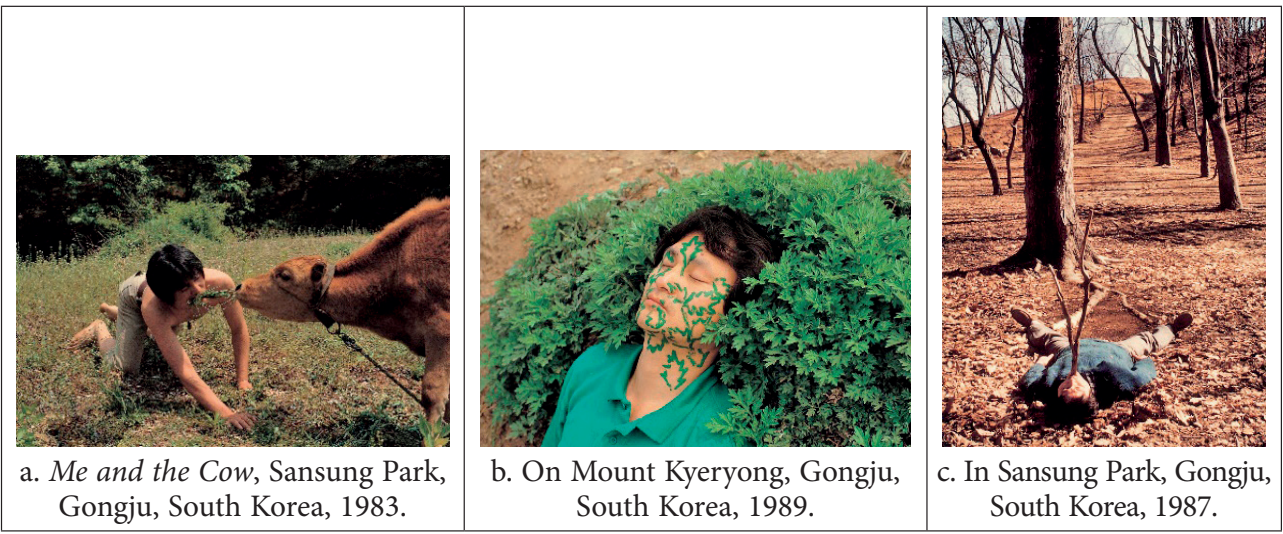

In particular, Ko's appreciation of nature is linked to religious piety; Yun Jo Park (2013) described Ko's practice as an earnest effort to bring art and religious worship into nature (see Table 2). As Ko puts it, "I consider nature as mother and teacher. From the ever-changing nature and its full vitality, I have learned humility and patience and experienced the warm helping hand of God, the creator" (Ko, Paek 2017). In a recent interview with me, Ko told me that, from the beginning of his practice, he was conscious of the absoluteness of nature and its enormous power to bring seasonal changes, which prompted him to search for "The Author" of all beings. For Ko, art practice in nature became an acting of worshipping God, the creator of all things.

Table 2. Works reflecting Seung-Hyun Ko’s religious piety (source: Courtesy of Yatoo)

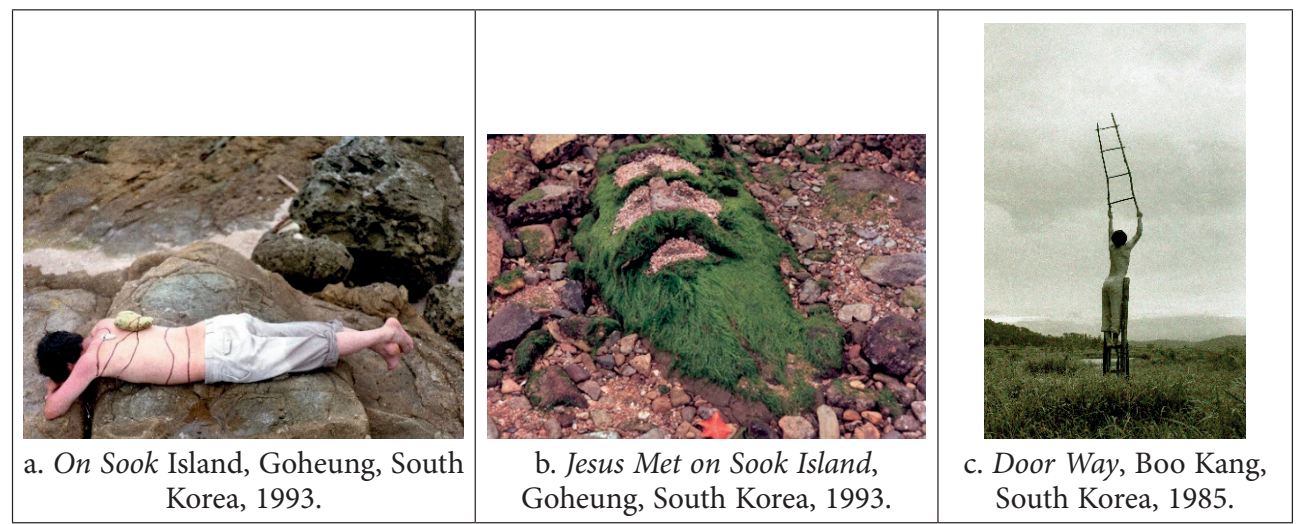

Ko's modest practice in nature was disrupted by the significant increase in social activities that followed the international exhibitions hosted by Yatoo from the early 1990s onward. In the in-person interview, Ko shared his concerns about his practice in nature, which eventually motivated him to consider sound as a medium for his work:

"We formed the outdoor art research group, Yatoo, to be free from the conventions of installing and exhibiting works of art. But large-scale outdoor exhibitions demanded 
extra works just for their shows. The events required some sort of eye-catching, factitious works to be installed in nature. That bothered me a lot because nature was already a perfect being [such] that there was little to add or take out. I was serious about my role as an artist. Then, one day, I saw someone playing a haegeum [a traditional Korean string instrument] and was deeply moved by the beautiful melody. I thought, if it's not possible to create anything better in nature, then, perhaps, I can create sounds that go well with the diverse sounds of life in nature" (Ko, Paek 2017).

\subsubsection{Sound creation practice in the 2000s}

Since 2000, Ko has been working on a gayageum project entitled "The Sound of a Hundred Years" and has installed more than 20 gayageums in many countries around the world (Jeon, 2017). Based on a traditional gayageum, Ko has created his own versions of the instrument, using dead trees found in the locales where he has worked (see Table 3). Asked why he kept working on this project, Ko explained: "Sounds seem to make a stronger impression than visual objects do. People tend to be moved more deeply by hearing than by looking. Also, sounds can be shared with a wider audience" (Ko, Paek 2017).

Table 3. Seung-Hyun Ko at work on his gayageum project (source: Courtesy of Yatoo)

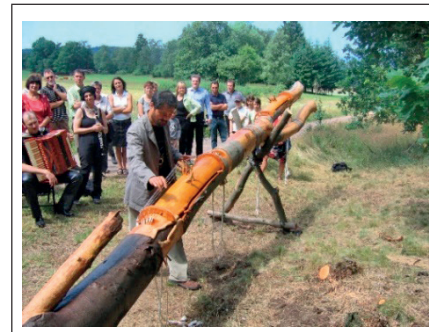

a. In Sachsenberg, 2005.

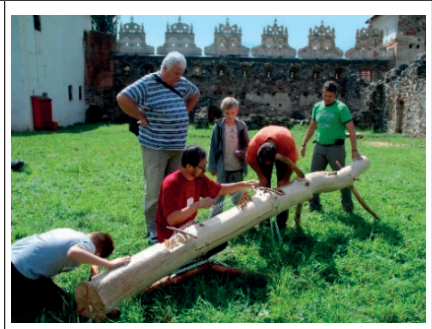

b. In Lazarea, 2007.

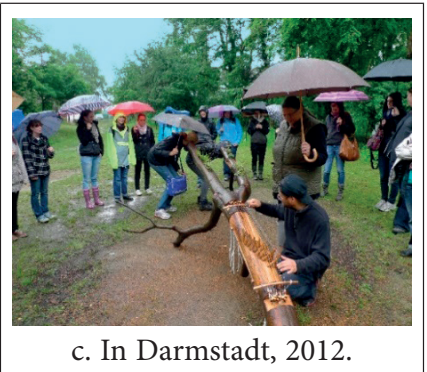

c. In Darmstadt, 2012.

As to the purpose of the work, he said, "I like to give a message; when it [the sound that I made] is blended in with the sound of nature, the nicely blended sound can touch our feelings, and the value of such work is that it can be shared with more people". Ko's effort to create sounds that can coexist harmoniously with nature echoes Suzi Gablik's (1992) concept of "connective aesthetics", referring to art that places less emphasis on individual creativity in favor of interconnectedness and interdependence (Inwood, 2008).

\subsubsection{Extended practice since 2010}

Although there were concerns over Yatoo's engagement in large-scale exhibitions, the group continued to extend the scope of its external activities (Jeon, 2016; Jin, 2016). International exchanges became more systematic, expanding and diversifying further with the launch of an international biennale in 2004; an international residence program that commenced in 2009; an online international networking program (Yatoo-i) in 2011; and a Global Nomadic Art Project (GNAP) in 2014. Ko's view of nature appears to have been significantly broadened by his participation in the seven-year GNAP project (2014-2020), traveling across continents "to re-instigate people's awareness, concern, learning, and responsibility towards our environment $\langle\ldots\rangle$. In the frame of the GNAP projects, nature artists from all over the world 
wander in different places of the globe" (GNAB: Geumgang Nature Art Biennale, 2019). Each year, artists gather in a particular region to explore the local environment and to create nature-based works with local artists. They document the process with cameras and videos for exhibition in galleries in that country (Table $4 \mathrm{a}, 4 \mathrm{~b})$.

Table 4. Global nomadic art project activities in South Africa (source: Courtesy of Yatoo)

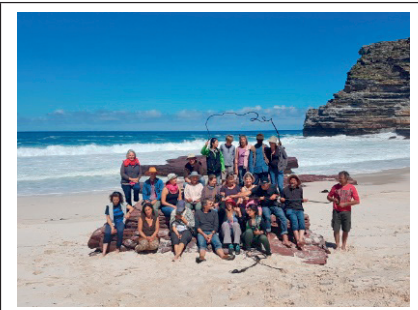

a. Global Nomadic Art Project workshop in South Africa, 2016.

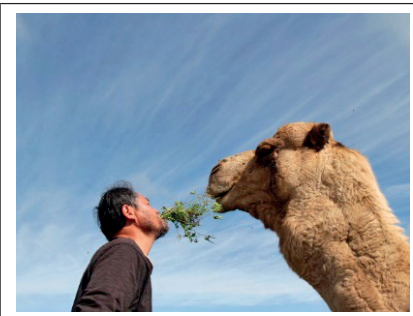

b. Seung-Hyun Ko. Me and the Camel. South Africa, 2016.

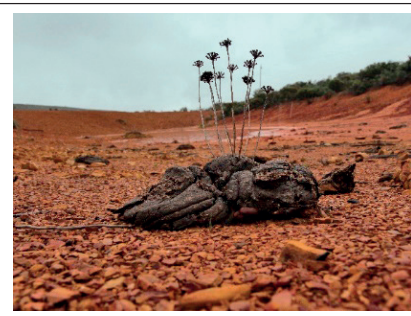

c. Seung-Hyun Ko. Cowpat. South Africa, 2016.

Ko's practice in the GNAP workshops appears to be influenced by his recent involvement in the SW project. While Me and the Camel (Table 4b) can be seen to reflect his continuing interest in communing with nature following his 1983 work with a cow, Cowpat (Table 4c) seems to relate to the values of SW. The simple act of putting a few tiny wild flowers in a cowpat found in the wild seems to embody the project's goal of re-capturing the value of what has long been considered useless and unwanted waste to be flushed away.

Ko's extended practices in recent years indicate a broadening of his view of nature. Shortly after his trip to South Africa for the 2016 GNAP workshop, I invited Ko to talk to engineering students in my art class. Sharing the concerns of local environmentalists he had met on his journey, Ko noted that traveling to such a dry and barren land helped him to realize the value and potential contribution of the ongoing Science Walden research. As he remarked,

\footnotetext{
"Although I have practiced in nature for so long, such an ecological issue has not been a significant part of my concern as an artist. The trip was certainly an occasion for me to think about our relationship to environment" (Ko, Paek 2017).
}

\subsection{Ko's practice in the context of Science Walden}

SW has involved two stages. During the first stage (Fall 2015-Winter 2016), research activities were mostly exploratory, forming the basis for the more focused research practice of the second stage (August 2017-February 2022). In the first stage, more than 20 registered research collaborators from diverse disciplines have participated in the project; as one of these collaborators, Ko has initiated, developed and participated in several projects in collaboration with other researchers.

\subsubsection{Science Walden Pavilion}

At the outset, one of our priorities in getting the project moving was to secure a multifunctional laboratory. In the initial group discussion, activities envisioned for this space included 
testing of a non-flushing toilet system and a rainwater harvesting system; scientific experiments to develop bio-energy production from feces; testing the use of compost converted from feces to cultivate crops; relevant artistic explorations; and development of diverse sociocultural programs to support research activities and public communications. While struggling to find a professional architect to build such a conceptually complex structure on a limited budget, there was an unexpected response from within our research group. As an artist with experience of constructing several buildings, Ko proposed a two-story hexagonal pavilion modeled on a honeycomb (see Table 5a). Based on our initial discussions, he drafted several key interior components: 1) a green roof installation for rainwater harvesting (Table 5d); 2) a space on the first floor for scientific experimental equipment (Table $5 \mathrm{~g}$ ) and a non-flushing toilet system (Table 5h); 3) a space for displaying artwork connected with the non-flushing toilet system (Table 5i) and the rainwater harvesting system (Table 5e); 4) a space on the second floor for diverse sociocultural activities such as group meetings and movie screening (Table 5f); and 5) finishing materials that would facilitate plant growing by allowing sunlight to penetrate the outer walls (Table $5 \mathrm{c}$ ).

Table 5. Interior and exterior views of pavilion (source: Courtesy of Yatoo and Science Walden)

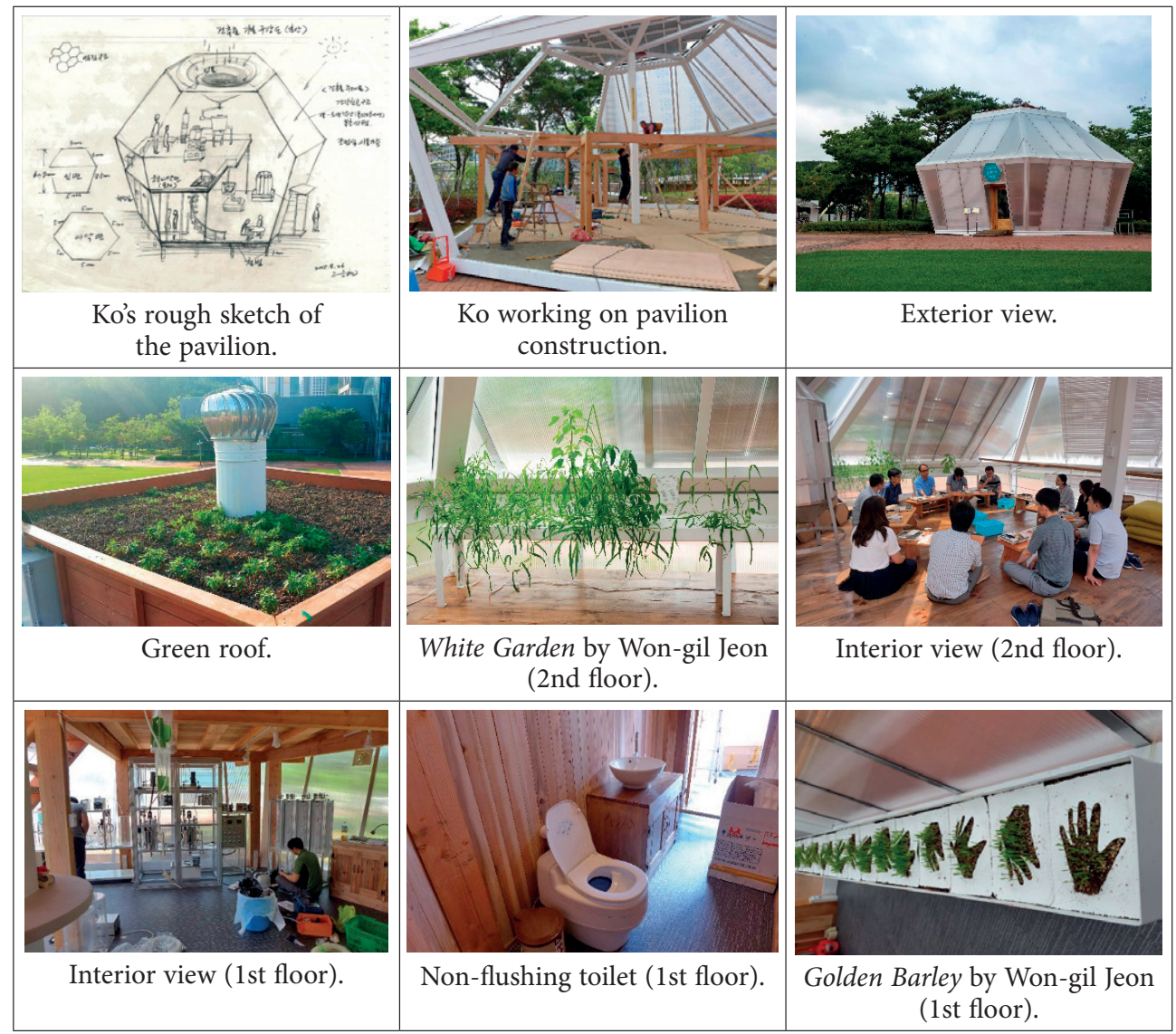


In undertaking the construction work (Table 5b), Ko developed a detailed plan by exchanging ideas with the other researchers. While most discussions centered on the efficiency, capacity, and safety of the equipment to be installed, Won-gil Jeon (another Yatoo artist) suggested the creation of artworks that integrated well with the scientific concepts - for example, using compost made from feces processed through the non-flushing toilet system to grow barley sprouts (Table $5 \mathrm{i}$ ) and using rainwater processed through the water purification system to grow plants (Table 5e). During this process, visible differences were observed between artists and scientists in terms of their focus and attitude. While the artists took the initiative to create an unusual structure, incorporating scientific concepts into their work process, the science researchers appeared nervous about adopting something unstructured or unconfirmed. As Ko noted, "The questions I heard in the earlier stage of construction were mostly related to technical issues, such as structural durability and stability, which I had not seriously considered before" (Ko, Paek 2017). He characterized the differences in work orientation as follows:

"It may be a matter of tendency. I think scientists tend to begin their work when everything has been clearly set up, whereas artists initiate the work when they have an urgent feeling of something to express. Scientists work by plan and look for a perfect completion, whereas artists work by intuition and look for opportunities to open up possibilities. I believe such differences allow room for more productive complementary cooperation, through which each side may find something unexpected by chance" (Ko, Paek 2017).

As the person in charge of constructing the building, that perspective informed his experience of these conflicts in the work process: "Collaboration won't be easy. It certainly requires endurance and effort to understand each other's tendency. Nevertheless, I look forward to coming opportunities more than obstacles" (Ko, Paek 2017). Not surprisingly, he assigned more value to the positive aspects of this challenging experience.

\subsubsection{ArscilioN: Invited Fishes}

Ko constructed a second version of the hexagonal pavilion in collaboration with his Yatoo colleague Jeon and Jaeweon Cho, an engineer directing the SW project, and this was installed in a local creek known as Jemin in Gongju, where Yatoo is based (see Table 6a). Entitled ArscilioN (a mixed term incorporating art, science, and pavilion), this represented a further outcome of the collaboration between art and science practitioners. This work was initially conceived as a way of involving SW in Yatoo's forthcoming international biennale in Gongju in fall 2016. Following successful completion of the first pavilion on campus, ArscilioN was planned in detail on the basis of Jeon's proposal for raising public awareness of the local environment. The design invited fish living in the local creek into the water tank, which was installed in the pavilion (Table 6b). Jaeweon Cho contributed his environmental engineering knowledge to build a water purification unit (Table $6 c, 6 \mathrm{~d}$ ).

ArscilioN remained open to the public for the three months of the biennale. According to Ko, it was generally well received, and residents and biennale visitors alike were pleased to see such a structure installed over the creek and crossing a residential area. While students showed particular interest in the hand-operated purification system, Ko noted that 
Table 6. ArscilioN (source: courtesy of Yatoo)

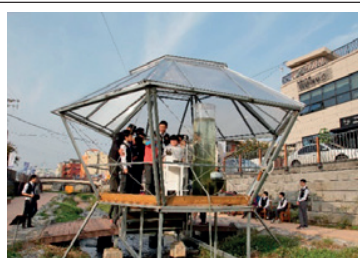

a. Seung-hyun Ko, Won-gil Jeon, Jaeweon Cho, ArscilioN: Invited Fish, Jemin creek, Gongju, 2016.

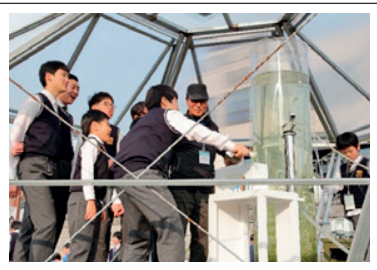

b. A student engages with the hand-operated purification system.

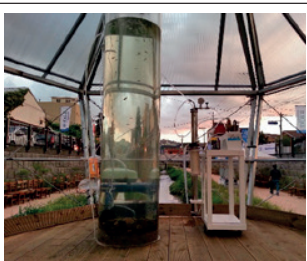

c. Cylindrical water tank (left) and water purification system (right).

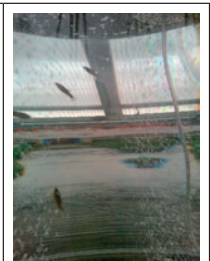

d. Fish in the water tank.

the administrative officers responsible for the local environment were more interested in the pavilion's safety, durability, and daily management. Ko also noted the gap between the conceptual plan and its realization:

\begin{abstract}
"The pavilion was built with a well-intended purpose of creating an occasion for people to think about local environmental issues, such as water pollution, renewable resources, and restoration of the ecological system. However, when it was opened, technical problems emerged. There was much more sunlight beating down on the water tank than we had expected, and this caused a rapid increase in algal bloom, which increased much faster than the water could be purified. Regardless of the unexpected outcomes, our idea has been tested, and we saw possibilities" (Ko, Paek 2017).
\end{abstract}

Ko commented on this trial and error approach: "I learned that a public installation such as this couldn't work well with a rough plan; it should be initiated with a well thought-out plan" (Ko, Paek 2017). Ko's response to the challenges and opportunities emerging from this collaborative practice of building public structures incorporating scientific concepts discloses the potential growth of the CP in this interactive social context.

\title{
4. Social dimensions of the creative process
}

The social dimensions of Ko's CP in two interrelated contexts reveal the value of creative dynamics in the context of IR.

\subsection{Creative response to the emergent challenges of collective practice in nature}

Through diverse activities with his colleagues in Yatoo, Ko has been developing his own way of communing with nature, and a few aspects of Ko's practice reflect its social context. The first of these is regionality. Ko has been working in a less industrialized region; surrounded by mountains and a major river, and there is a strong sense of the local culture inherited from the time when the area was the capital of an ancient kingdom that flourished in the Korean Peninsula (Paek, 2019). The region's geographical and sociohistorical particularity seems to have influenced how Ko and his Yatoo colleagues became conscious of their environment and how they navigated a path to commune with nature. A second social aspect of Ko's art 
practice is its collective form. Working as a group under the name Yatoo has provided Ko with an important space for sharing interests, exchanging ideas, and organizing programs and events. In particular, the Yatoo artists have developed unique methodologies for their site-based art practice through a form of collective practice: the Four Season Nature Art Workshop (Jeon, 2016). As a regular four-season event since the community's inception, the workshop has served to maintain the value of direct contact with nature for the member artists (Paek, 2019). A third social dimension is Ko's position as a leading artist in Yatoo, which has enabled him to boost internal and external communications by organizing domestic and international events and programs. The breadth and depth of Ko's practice has extended still further in recent years, confirming the influence of Yatoo's international exchanges in more systematic programs like the GNAP launched in 2014.

As a significant outcome of Ko's creative response to the challenges of collective practice in nature, the gayageum project marks a major change in his practice, born of the conflict between the outcome-oriented practice associated with the growth of Yatoo's social activities in recent years and the community's traditional process-oriented practice. Against the changing direction, Ko looked for ways to strengthen what made Yatoo's practice unique - the focus on communing with nature with minimal manipulation. As well as preserving the core vision of Yatoo's site-based practice, the gayageum project enabled Ko to extend his visual art practice to audio, creating sounds to be integrated into nature. In this sense, Ko's gayageum project should be appreciated as a creative contribution to the broader field of ecological art.

\subsection{Creative responses to the emergent challenges of collaborative practice}

The social context of Ko's practice in SW center has generated some notable cultural conflicts, especially in his exposure to diverse and unfamiliar scientific ways of thinking and doing. Although the center welcomes practitioners and researchers in the arts and humanities, it is directed by environmental engineers, and more than fifty percent of its researchers have an engineering background. As one of two artists who participated in the project during its first two years, Ko admitted that collaborating with a group of engineering students and researchers required him to navigate his role within the project's social context.

The SW Pavilion represents a significant outcome of Ko's creative responses as an artist to the needs of a community in the early stages of project development as an interdisciplinary space for exploring and developing ideas for reconstructing ecologically sustainable living systems based on renewable energy resources. This work established his position at the center of the project, as it required him to define the project's key conceptual directions and to translate these into a concrete structure into which the practical needs of researchers from diverse backgrounds could be integrated. It was interesting to see how Ko viewed building this complicated and challenging space on a very limited budget as an opportunity while many professional architects focused on the obstacles involved. Ko's positive response to such challenges reflects a creative mind that seeks to exploit the possibilities afforded by unexpected encounters (Eisner, 2002), again highlighting the potential contribution of art to IR. 


\section{Potential contributions of art to interdisciplinary research}

In particular, Ko's collaborative practice demonstrated the value of incorporating a possibilitydriven, ill-structured approach into a perfection-oriented, well-structured approach (Efland, 1995). The contextual analysis in this study identifies some evidence of changes in Ko's view influenced by his recent involvement in a number of external activities, especially through the GNAP and the SW research project. Potential growth through collaborative learning is reflected in the changing aspects of his view (Pluut \& Curşeu, 2013). One of these aspects is seen in his attitude toward nature. Ko has worked with nature for several decades, focusing on his personal relationship with it, and has now begun to pay attention to environmental problems and their social impact, as is evident in his recent work Cowpat (2016). Another aspect is his integrated views on scientific approaches. As an artist, Ko tended to value intuition more than rationality or predictive efficiency, but he now seeks ways to incorporate the scientific thinking process, which is evident in his recent collaborative project ArscilioN.

At the same time, clear evidence of the potential contributions of art within an interdisciplinary context was apparent in Ko's initiative in conceptualizing and building the first pavilion, responding to the project's need to organize and visualize ill-defined research ideas and concepts at the exploratory stage. The second pavilion, ArscilioN, provides another example of art's potential to serve as a venue for integrating disciplines and extending environmental principles and practices directly into the community (Rosenthal, 2003). This collaborative completion of the structure and its installation as a public space illustrates art's unique capability to engage people and to build support for collective action and behavioral change (Curtis et al., 2012). The more intrinsic power of art is illuminated by Ko's intuitive work Cowpat (Table 4c), in which Ko uses the image of a few tiny wildflowers growing out of an abandoned cowpat to raise public awareness of what has long been undervalued in a creative and affective way that conventional scientific and technocentric approaches cannot match (Aguilar et al., 2008; Gurevitz, 2000). This account of Ko's art practice finds support for the role of art as advocated by many educationalists: "the arts provide forms of inquiry that engage our minds, our senses, and our creative and inventive capacities. They provide a language of possibility for futures yet to be imagined <... " (Arts Education Partnership, 2007, p. 10).

\section{Conclusions}

Drawing on a CV of creativity that stresses the importance of the social context in which the efforts of individuals emerge and are assessed, Ko's recent collaborative practice in SW was examined in relation to the larger context of his long-term practice as a leading artist of a bioregionally conscious artist community. Ko's responses to the opportunities and challenges of his involvement in these two interrelated contexts show the transformative dynamics created in the context of IR, which holds the potential to facilitate and foster creative interactions and learning (Steelman et al., 2018). The collaborative art practice reviewed in this study provides insight into what facilitates creative contributions of individual artists in IR settings as well as implications for the continued growth of IR practices across the fields of science and technology. 


\section{Funding}

This work was supported by the National Research Foundation of Korea grant funded by the Government of South Korea (Ministry of Science, ICT and Future Planning) (No. NRF2015R1A5A7037825).

\section{References}

Aguilar, O. M., Waliczek, T. M., \& Zajicek, J. M. (2008). Growing environmental stewards: The overall effect of a school gardening program on environmental attitudes and environmental locus of control of different demographic groups of elementary school children. HortTechnology, 18(2), 243-249. https://doi.org/10.21273/HORTTECH.18.2.243

Arts Education Partnership. (2007). Working partnerships: professional development of the arts teaching workforce. Retrieved from http://www.aep-arts.org/wp-content/uploads/Working-Partnerships-1.pdf

Blandy, D., Congdon, K. G., \& Krug, D. H. (1998). Art, ecological restoration, and art education. Studies in Art Education: A Journal of Issues and Research, 39(3), 230-243. https://doi.org/10.2307/1320366

Cho, J. (2017). Philosophy of convergence research: "Science Walden", convergence research project of science and art. Convergence Research Review, 3(6), 33-64.

Cho, J. (2019). 2016: What do you consider the most interesting recent (scientific) news? What makes it important? Edge. Retrieved from https://www.edge.org/response-detail/26660

Csikszentmihalyi, M. (2014). The systems model of creativity: the collected works of Mihaly Csikszentmihalyi. New York: Springer Science+Business Media Dordrecht.

Curtis, D. J., Reid, N., \& Ballard, G. (2012). Communicating ecology through art: what scientists think. Ecology and Society, 17(2). Retrieved from https://www.ecologyandsociety.org/vol17/iss2/art3/

Efland, A. D. (1995). The spiral and the lattice: changes in cognitive learning theory with implications for art education. Studies in Art Education: A Journal of Issues and Research, 36(3), 134-153. https://doi.org/10.2307/1320905

Eisner, E. W. (2002). The arts and the creation of mind. New Haven, CT: Yale University Press.

Gablik, S. (1992). Connective aesthetics. American Art, 6(2), 2-7. https://doi.org/10.1086/424147

Garoian, Ch. R. (1998). Art education and the aesthetics of land use in the age of ecology. Studies in Art Education, 39(3), 244-261. https://doi.org/10.2307/1320367

GNAB: Geumgang Nature Art Biennale. (2019). Rural stages: GNAP 2017, Eastern Europe. Gabrovtsi, Bulgaria - Lazarea, Romania - Noszvaj, Hungary, 1-31 July, 2017. Retrieved from http://www. natureartbiennale.org/bbs/board.php?bo_table=nomadic\&wr_id=110\&lang=eng

Gurevitz, R. (2000). Affective approaches to environmental education: going beyond the imagined worlds of childhood? Ethics, Place and Environment: A Journal Philosophy \& Geography, 3(3), 253268. https://doi.org/10.1080/713665905

Hadzigeorgiou, Y., \& Skoumios, M. (2013). The development of environmental awareness through school science: problems and possibilities. International Journal of Environmental \& Science Education, 8, 405-426.

Hollis, C. L. (1997). On developing an art and ecology curriculum. Art Education, 50(6), 21-24. https://doi.org/10.2307/3193684

Inwood, H. J. (2008). At the crossroads: situating place-based art education. Canadian Journal of Environmental Education, 13(1), 29-41.

Jacobson, S. K., Seavey, J. R., \& Mueller, R. C. (2016). Integrated science and art education for creative climate change communication. Ecology and Society, 21(3). Retrieved from https://www.ecologyandsociety.org/vol21/iss3/art30/ 
Jeon, W. (2017). A prayer through Seung-Hyun's Ko Kayageum: The sound of hundred years. In S. Ko, Kayageum: The Sound of Hundred Years, 6-7. Retrieved from https://en.calameo.com/ $\mathrm{read} / 0019600633 \mathrm{f} 24 \mathrm{f} 9 \mathrm{a} 69304$

Jeon, W. (2016). Yatoo-i: Yatoo International Project. Retrieved from http://www.yatooi.com/ Yatooi?ckattempt $=1$

Jin, S. (2016). A study on Korean nature artists' association - Yatoo (Master's Thesis). Seoul, Hongik University [unpublished source].

Ko, S.-H., \& Paek, K.-M. (2017). The practice in nature. Personal Interview (unpublished source).

Kollmuss, A., \& Agyeman, J. (2002). Mind the gap: why do people act environmentally and what are the barriers to pro-environmental behavior? Environmental Education Research, 8(3), 239-260. https://doi.org/10.1080/13504620220145401

Lee, S. (2000). A Study on the Yatoo - nature art: centering on the study of four seasons' in nature (Master's Thesis). South Chungcheong Province, Kongju National University (unpublished source).

Neperud, R. W. (1997). Art, ecology and art education: practices \& linkages. Art Education, 50(6), 1420. https://doi.org/10.2307/3193683

Paek, K.-M. (2019). Communing with nature: the collective journey of Yatoo artists and its pedagogical potentials. The International Journal of Art \& Design Education, 38(1), 240-255. https://doi.org/10.1111/jade.12182

Park, Y. (2013). A study on nature space/place of Lee Seung Taek and Ko Seung Hyun. Journal of Basic Design \& Art, 14(4), 243-253.

Pluut, H., \& Curşeu, P. L. (2013). The role of diversity of life experiences in fostering collaborative creativity in demographically diverse student groups. Thinking Skills and Creativity, 9, 16-23. https://doi.org/10.1016/j.tsc.2013.01.002

Rosenthal, A. T. (2003). Teaching systems thinking and practice through environmental art. Ethics and the Environment, 8(1), 153-168. https://doi.org/10.1353/een.2003.0013

Skinner, B. F. (1948). Walden two. Indianapolis, IN: Hackett Publishing Company.

Spaid, S. (2002). Ecovention: current art to transform ecologies. Cincinnati, OH: The Contemporary Arts Center.

Steelman, T. A., Andrews, E., Baines, S., Bharadwaj, L., Bjornson, E. R., Bradford, L., Cardinal, K., Carriere, G., Fresque-Baxter, J., Jardine, T. D., MacColl, I., Macmillan, S., Marten, J., Orosz, C., Reed, M. G., Rose, I., Shmon, K., Shantz, S., Staples, K., Strickert, G., \& Voyageur, M. (2018). Identifying transformational space for transdisciplinarity: using art to access the hidden third. Sustainability science. Retrieved from https://link.springer.com/article/10.1007\%2Fs11625-018-0644-4

Sternberg, R. J. (2006). The nature of creativity. Creativity Research Journal, 18(1), 87-98. https://doi.org/10.1207/s15326934crj1801_10

Sullivan, G. (2007). Creativity as research practice in the visual arts. In L. Bresler (Ed.), International handbook of research in arts education (pp. 1181-1194). Dordrecht: Springer. https://doi.org/10.1007/978-1-4020-3052-9_81

Thayer, Jr. R. L. (2003). Lifeplace: bioregional thought and practice. Berkeley: University of California Press.

Thoreau, H. D. (1854). Walden, or life in the woods. Boston: Ticknor and Fields. https://doi.org/10.5962/bhl.title.146169

Walker, H. (2001). Interviewing local artists: a curriculum resource in art teaching. Studies in Art Education: A Journal of Issues and Research, 42(3), 249-265. https://doi.org/10.2307/1321040 


\title{
MENININKO KÜRYBINIS INDE்LIS I TARPDALYKINIŲ TYRIMŲ KONTEKSTĄ
}

\author{
Kyong-Mi Paek \\ Santrauka
}

Nors lūkesčiai dèl galimo meno indèlio ị tarpdalykinių mokslinių tyrimų kontekstą ir toliau auga, paskirų menininkų kūrybinès pastangos lieka nepakankamai išnagrinètos galbūt dẻl nustatytų bendrojo moksliniams tyrimams taikomo tarpusavio santykių pobūdžio. Siekiant ištirti, kaip mokslininkai integruoja savo indèlị $\mathfrak{i}$ konkrečią mokslinius tyrimus atliekančią bendruomenę, šiame straipsnyje apžvelgiama meno praktika, plètojama Seung-Hyuno Ko, dirbusio Konvergencinių mokslinių tyrimų centre Science Walden, kuriame vykdomas tarpdalykinis mokslinių tyrimų projektas, o šio tikslas - sukurti ekologiniu požiūriu tvarią bendruomenę. Remiantis išsamiais požiūriais ị kūrybiškumą, pabrezžiančiais socialinio konteksto, kuriame randasi individualios pastangos ir kuriame jos yra įvertinamos, svarbą, straipsnyje tyrinèjama naujausia Ko bendradarbiavimo praktika, išplètota Science Walden. Tai daroma išsamesniame jo, kaip lyderiaujančio Yatoo - bioregionine prasme sąmoningų menininkų bendruomenei priklausančio menininko - ilgalaikès praktikos kontekste. Ko atsakas ị jo ịsitraukimo nulemtas galimybes ir iššūkius šiuose dviejuose tarpusavyje susijusiuose kontekstuose atskleidžia tarpdalykinių mokslinių tyrimų kūrybinès dinamikos vertę ir vis skirtingesnių tarpdalykinių mokslinių tyrimų praktikų, iškylančių moksle ir technologijose, reikšmes.

Reikšminiai žodžiai: bendradarbiavimas, išsamūs požiūriai, kūrybinė praktika, tarpdalykiniai moksliniai tyrimai, Science Walden, Yatoo. 